\title{
EU energy policies achievement by industries in decentralized areas
}

\author{
Nicola Destro ${ }^{1, *}$, Anna Stoppato $^{1}$, Alberto Benato $^{1}$, and Fabio Schiro ${ }^{1}$ \\ ${ }^{1}$ Department of Industrial Engineering (DII), University of Padova, Via Venezia 1, 35131 Padova, \\ Italy
}

\begin{abstract}
Energy Roadmap outlined by the European Commission sets out several routes for a more sustainable, competitive and secure energy system in 2050. All the outlined scenarios consider energy efficiency, renewable energy, nuclear energy and carbon capture and storage. In this paper, more attention has been devoted to the energy efficiency issue, by the identification of new micro and small networks opportunity fed by hybrid plants in the North-East of Italy. National energy balance and national transmission system operator data allowed to collect industrial energy consumptions data on the investigated area. Applying industrial statistics to the local energy needs allows to collect a dataset including consumption information by factory and by company structure (size and employees) for each industrial sector highlighting the factory density in the area. Preliminary outcomes from the model address to the exploitation of local by-product for energy purposes.
\end{abstract}

\section{Introduction}

The European Commission policy is offering significant opportunities for public and private investment to support growth, employment and structural transformation. The new generation of programmes under the European Structural and Investment Funds (ESI Funds) 2014-2020 is focused on 11 thematic objectives. Some of them are related to strengthening research, technological development and innovation, competitiveness of Small and Medium Enterprises (SMEs), supporting the transition towards a low-carbon economy [1]. The industry energy efficiency levels are expected to be improved up to 2050 in several industrial sectors. Iron, steel, chemicals and pharmaceuticals industries are the most involved in this process because it is expected an increment of their energy consumption due to the production growth despite the energy intensity improvement. In pulp and paper industries an energy intensity improvement and an energy consumption reduction is expected despite a gradual increase in production rates. In the non-metallic minerals sector energy intensity is expected to remain flat for ceramics, cement and glass sectors as well as for non-ferrous metals industries. Food and drink sector is subject to a continuous improvement leading to the energy consumption reduction despite the growth of production. Energy consumption of the petroleum refineries sector is assumed to decrease the energy consumption due to the past energy efficiency improvement and due to the demand reduction [2]. 


\section{Italian Company Structure}

The Italian data warehouse of the Industry and Services Census 2011 contains a wealth of detailed information on the main features of businesses, non-profit and public institutions, disaggregated at the regional level. The census reference date is $31^{\text {st }}$ December 2011. From census returns, it is possible to derive information related to the main structural characteristics of businesses, non-profit and public institutions: legal form, economic activity, human resources and geographic location. The Italian National Institute of Statistics arranges economic activity using the ATECO 2007 classification which is the national version of the European nomenclature, Nace Rev. 2 [3].

The area investigated in this paper is composed by four Italian Regions, often regarded as North-East of Italy. The considered regions are: Trentino Alto Adige, Veneto, FriuliVenezia Giulia and Emilia Romagna. Using the Census 2011 a first description of the overall area under investigation is summarized in Table 1.

Table 1. Comparison between Italian and North-East enterprises structure.

\begin{tabular}{|c|c|c|c|c|c|c|c|c|}
\hline & \multicolumn{4}{|c|}{ Number of enterprises } & \multicolumn{4}{c|}{ Number of employees } \\
\hline $\begin{array}{c}\text { Size class of } \\
\text { employees }\end{array}$ & $\mathbf{3 - 1 9}$ & $\mathbf{2 0 - 9 9}$ & $\begin{array}{c}\mathbf{0 v e r} \\
\mathbf{1 0 0}\end{array}$ & $\mathbf{T o t a l}$ & $\mathbf{3 - 1 9}$ & $\mathbf{2 0 - 9 9}$ & $\begin{array}{c}\mathbf{0 v e r} \\
\mathbf{1 0 0}\end{array}$ & Total \\
\hline Italy & 191030 & 29098 & 4615 & 224743 & 1325280 & 1125403 & 1158713 & 3609396 \\
\hline North-East & 50494 & 9595 & 1592 & 61681 & 371281 & 371126 & 359312 & 1101719 \\
\hline North-East [\%] & $26.4 \%$ & $33.0 \%$ & $34.5 \%$ & $27.4 \%$ & $28.0 \%$ & $33.0 \%$ & $31.0 \%$ & $30.5 \%$ \\
\hline
\end{tabular}

In Table 1 enterprises with less than three employees are not considered due to their little energy consumption. Note that these neglected enterprises account for the $85 \%$ of the whole industrial employees in the North-East of Italy. The regions account for the $27.4 \%$ of the Italian enterprises and the $30.5 \%$ of the industrial labour force. In the North-East the $81.9 \%$ of enterprises has a workforce between 3 and 19 employees, the $97.4 \%$ of enterprises has a workforce between 3-99 employees while just the $2.6 \%$ of enterprises has more than 100 employees.

Table 2. Comparison between Italian and North-East enterprises structure.

\begin{tabular}{|c|c|c|c|c|}
\hline & \multicolumn{2}{|c|}{ Enterprises } & \multicolumn{2}{c|}{ Local units of enterprises } \\
\hline & $\begin{array}{c}\text { number of } \\
\text { active units }\end{array}$ & $\begin{array}{c}\text { number of } \\
\text { employees }\end{array}$ & $\begin{array}{c}\text { number of } \\
\text { active units }\end{array}$ & $\begin{array}{c}\text { number of } \\
\text { employees }\end{array}$ \\
\hline Extraction of crude petroleum and gas & $0.00 \%$ & $0.00 \%$ & $16.55 \%$ & $10.44 \%$ \\
\hline Coke and refined petroleum products & $9.88 \%$ & $4.18 \%$ & $12.36 \%$ & $5.77 \%$ \\
\hline Electricity, gas and steam supply & $25.13 \%$ & $14.68 \%$ & $21.45 \%$ & $22.67 \%$ \\
\hline Water supply and management & $16.33 \%$ & $15.76 \%$ & $16.86 \%$ & $16.78 \%$ \\
\hline Iron and steel, non-ferrous metals & $22.02 \%$ & $21.75 \%$ & $23.03 \%$ & $24.04 \%$ \\
\hline Chemical and pharmaceutical & $23.05 \%$ & $17.20 \%$ & $23.54 \%$ & $20.01 \%$ \\
\hline Non-metallic minerals & $25.19 \%$ & $37.77 \%$ & $26.41 \%$ & $37.28 \%$ \\
\hline Transport equipment & $27.00 \%$ & $17.05 \%$ & $25.97 \%$ & $16.45 \%$ \\
\hline Machinery & $31.03 \%$ & $35.31 \%$ & $31.18 \%$ & $35.78 \%$ \\
\hline Mining and quarrying & $17.50 \%$ & $18.76 \%$ & $19.05 \%$ & $19.40 \%$ \\
\hline Food products, beverages and Tobacco & $21.79 \%$ & $29.45 \%$ & $22.59 \%$ & $28.66 \%$ \\
\hline Paper products and print & $25.62 \%$ & $30.45 \%$ & $25.68 \%$ & $29.61 \%$ \\
\hline Wood products & $31.83 \%$ & $36.80 \%$ & $32.00 \%$ & $37.58 \%$ \\
\hline Constructions & $21.19 \%$ & $22.71 \%$ & $21.32 \%$ & $22.89 \%$ \\
\hline Textiles, apparel, leather & $23.42 \%$ & $25.58 \%$ & $23.50 \%$ & $25.63 \%$ \\
\hline Other manufacturing & $31.93 \%$ & $36.64 \%$ & $32.12 \%$ & $36.75 \%$ \\
\hline
\end{tabular}


From the employees classification it is possible to claim that the $33.7 \%$ of them are working in enterprises with 3-19 employees, the 67.4\% are working in enterprises with 399 employees while the $32.6 \%$ are employed in enterprises with more than 100 employees. The percentage of industrial enterprises and local unit of enterprises on the region are related to the corresponding Italian amount.

\section{Energy consumption and cogeneration potential}

National energy balance published by Eurostat [4] provides information about industrial energy supplies. In this investigation the year 2013 has been considered as reference year. For the industrial sector and the energy industries the energy balance states 31.6 Mtoe of energy consumption. Assuming the whole consumption of fossil fuels for heating purpose and a conversion efficiency of $90 \%$ the heat request is estimated equal to 20.9 Mtoe. Heat is fulfilled for $19 \%$ by derived heat that includes self-production from combined heat and power plants (CHP). Electricity request is 10.7 Mtoe and fulfilled for $15 \%$ by self-produced electricity [5].

Table 3. Energy consumption of Italian enterprises.

\begin{tabular}{|c|c|c|c|c|c|c|c|c|}
\cline { 2 - 10 } \multicolumn{1}{c|}{} & $\begin{array}{c}\text { Total } \\
\text { products }\end{array}$ & $\begin{array}{c}\text { Solid } \\
\text { fuels }\end{array}$ & $\begin{array}{c}\text { Oil } \\
\text { (total) }\end{array}$ & Gas & $\begin{array}{c}\text { Total } \\
\text { Renewables }\end{array}$ & $\begin{array}{c}\text { Wastes } \\
\text { (non } \\
\text { ren.) }\end{array}$ & $\begin{array}{c}\text { Derived } \\
\text { heat }\end{array}$ & Electricity \\
\hline $\begin{array}{c}\text { ktoe } \\
\text { Extraction of crude } \\
\text { petroleum and gas }\end{array}$ & 835 & 0 & 0 & 786 & 0 & 0 & 18 & 31 \\
\hline $\begin{array}{c}\text { Coke and refined } \\
\text { petroleum products }\end{array}$ & 4894 & 35 & 3033 & 278 & 0 & 0 & 1082 & 467 \\
\hline Extraction of coal & 5 & 0 & 0 & 0 & 0 & 0 & 2 & 4 \\
\hline $\begin{array}{c}\text { Electricity, gas and } \\
\text { steam supply }\end{array}$ & 721 & 0 & 0 & 27 & 0 & 0 & 345 & 348 \\
\hline $\begin{array}{c}\text { Water supply and } \\
\text { management }\end{array}$ & 521 & 0 & 0 & 0 & 0 & 0 & 0 & 521 \\
\hline $\begin{array}{c}\text { Iron and steel, non- } \\
\text { ferrous metals }\end{array}$ & 5663 & 1923 & 92 & 1779 & 0 & 0 & 88 & 1781 \\
\hline $\begin{array}{c}\text { Chemical and } \\
\text { pharmaceutical }\end{array}$ & 4121 & 1 & 469 & 1053 & 7 & 71 & 1243 & 1276 \\
\hline $\begin{array}{c}\text { Non-metallic } \\
\text { minerals }\end{array}$ & 4984 & 241 & 1520 & 2004 & 96 & 202 & 108 & 814 \\
\hline $\begin{array}{c}\text { Transport } \\
\text { equipment }\end{array}$ & 365 & 0 & 0 & 0 & 0 & 0 & 79 & 286 \\
\hline Machinery & 3356 & 0 & 252 & 1387 & 1 & 0 & 15 & 1701 \\
\hline $\begin{array}{c}\text { Mining and } \\
\text { quarrying }\end{array}$ & 116 & 0 & 23 & 34 & 0 & 0 & 0 & 59 \\
\hline $\begin{array}{c}\text { Food products and } \\
\text { Tobacco }\end{array}$ & 2657 & 0 & 160 & 1174 & 30 & 0 & 266 & 1028 \\
\hline $\begin{array}{c}\text { Paper products and } \\
\text { print }\end{array}$ & 2020 & 0 & 63 & 613 & 0 & 0 & 564 & 781 \\
\hline Wood products & 404 & 0 & 0 & 31 & 89 & 0 & 27 & 256 \\
\hline Constructions & 361 & 0 & 33 & 217 & 0 & 0 & 0 & 111 \\
\hline $\begin{array}{c}\text { Textiles, apparel, } \\
\text { leather }\end{array}$ & 1167 & 0 & 81 & 586 & 0 & 0 & 40 & 459 \\
\hline $\begin{array}{c}\text { Other } \\
\text { manufacturing }\end{array}$ & 1067 & 3 & 42 & 19 & 52 & 8 & 129 & 813 \\
\hline
\end{tabular}


Eurostat energy balance provides detailed information of the produced energy by self-producers, in particular combined heat and power plants fed by fossil fuels: 1264 ktoe of electricity and 2000 ktoe of heat.

The detailed industrial energy consumption has been determined and is listed in Table 3.

From a literature review the estimation of the efficiency and the characteristics of combined heat and power plants has been obtained [5]. The wide range of industrial enterprises leads to analyse the system with average values for each industrial sector highlighting just the mean characteristics of each one. One of the most important tasks in CHP exploitation is the local use of heat. This topic can be summarized for each type of industry considering the amount of heat and its temperature. These information can be used to analyse the industrial cogenerative potential.

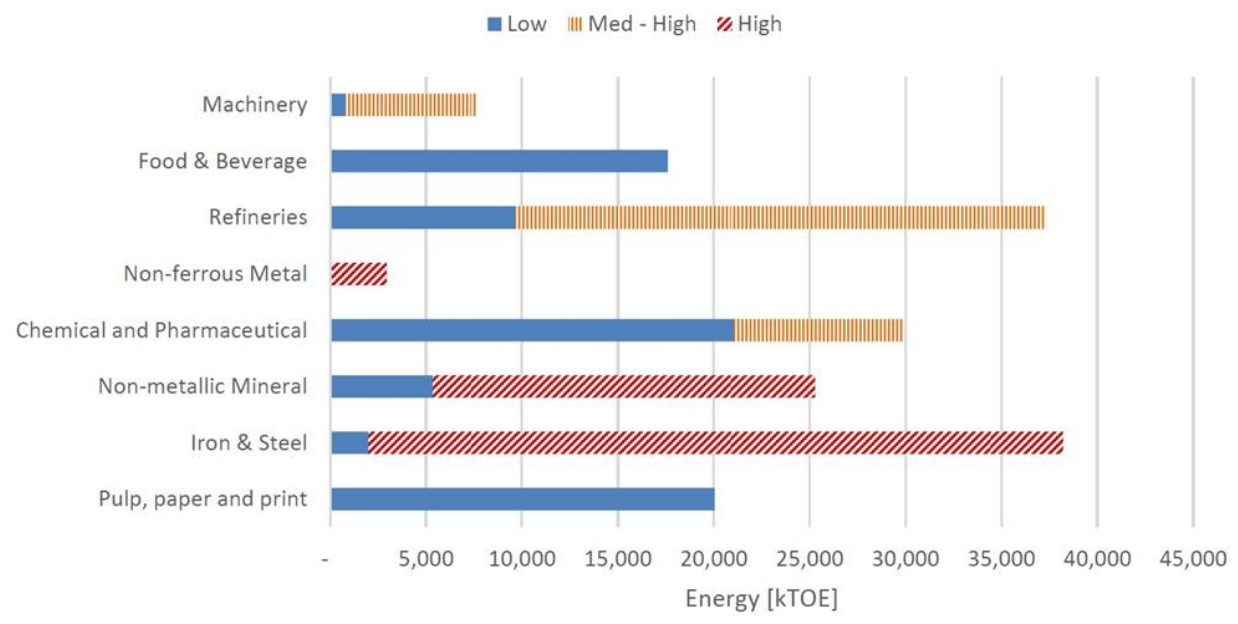

Fig. 1. Estimation of process heat temperature range [6].

For the main industrial sectors, the use of heat is categorized by temperature and by amount: it is possible highlighting the high percentage of industrial heat used at low temperature and the low amount of heat used at high temperature. Table 4 can lie out to identify the industry with high potential of cogeneration.

Table 4. Estimation of process heat temperature percentage.

\begin{tabular}{|c|c|c|c|}
\cline { 2 - 4 } \multicolumn{1}{c|}{} & low & med-high & High \\
\cline { 2 - 4 } \multicolumn{1}{c|}{} & $<\mathbf{2 5 0}{ }^{\circ} \mathbf{C}$ & $\mathbf{2 5 0 - 6 0 0} \mathbf{C}$ & $\mathbf{> 6 0 0}^{\circ} \mathbf{C}$ \\
\hline Machinery & $11 \%$ & $89 \%$ & $0 \%$ \\
\hline Food \& Beverage & $100 \%$ & $0 \%$ & $0 \%$ \\
\hline Refineries & $26 \%$ & $74 \%$ & $0 \%$ \\
\hline Non-ferrous Metal & $0 \%$ & $0 \%$ & $100 \%$ \\
\hline Chemical and Pharmaceutical & $70 \%$ & $30 \%$ & $0 \%$ \\
\hline Non-metallic Mineral & $22 \%$ & $78 \%$ & $0 \%$ \\
\hline Iron \& Steel & $4 \%$ & $96 \%$ & $0 \%$ \\
\hline Pulp, paper and print & $100 \%$ & $0 \%$ & $0 \%$ \\
\hline
\end{tabular}

The analysis of the industrial energy consumption allows to evaluate the energy efficiency improvement potential of each industrial sector through the installation of new combined heat and power plants.

Based on the data reported in Table 5, the actual CHP plants productions are 1497 ktoe of heat and 1300 ktoe of electricity. Estimated further productions from new CHP plants are 
1845 ktoe of heat and 1746 ktoe of electricity without considering economic and financial factors. Heat from boiler is determined as difference of fossil fuel consumption of each industrial sector and actual CHP consumption, assuming a boiler conversion efficiency of $90 \%$. Electricity from grid is determined as difference between electricity use and CHP actual production. The percentage of further heat from $\mathrm{CHP}$, CHP efficiency, and Heat/Electricity ratios, are estimated considering statistical data for each application.

Table 5. Estimation of new CHP production in Italy.

\begin{tabular}{|c|c|c|c|c|c|c|c|c|}
\hline & $\begin{array}{l}\text { Actual } \\
\text { Heat } \\
\text { from } \\
\text { CHP }\end{array}$ & $\begin{array}{c}\text { Actual } \\
\text { Electricit } \\
y \\
\text { from } \\
\text { CHP }\end{array}$ & $\begin{array}{l}\text { Heat } \\
\text { from } \\
\text { boiler } \\
\text { s }\end{array}$ & $\begin{array}{l}\text { Electricity } \\
\text { from grid }\end{array}$ & $\begin{array}{c}\text { Further } \\
\text { heat } \\
\text { from CHP }\end{array}$ & $\begin{array}{l}\text { Further } \\
\text { heat } \\
\text { from } \\
\text { CHP }\end{array}$ & $\begin{array}{l}\text { Heat/El } \\
\text { ectricit } \\
\text { y CHP }\end{array}$ & $\begin{array}{l}\text { Further } \\
\text { electricity } \\
\text { from } \\
\text { CHP }\end{array}$ \\
\hline & ktoe & Ktoe & ktoe & ktoe & $\%$ & ktoe & & ktoe \\
\hline $\begin{array}{l}\text { Chemical and } \\
\text { Petrochemical }\end{array}$ & 406 & 393 & 472 & 883 & 0.42 & 200 & 0.9 & 222 \\
\hline $\begin{array}{c}\text { Coke Ovens } \\
\text { and Refineries }\end{array}$ & 805 & 603 & 1427 & -135 & 0.11 & 151 & 0.9 & 168 \\
\hline $\begin{array}{c}\text { Food and } \\
\text { Tobacco }\end{array}$ & 162 & 192 & 874 & 899 & 0.24 & 209 & 1.1 & 190 \\
\hline Iron and Steel & 53 & 49 & 2913 & 1525 & 0.06 & 176 & 0.7 & 251 \\
\hline Machinery & 13 & 11 & 1447 & 1691 & 0.50 & 724 & 1.5 & 482 \\
\hline $\begin{array}{c}\text { Non-Ferrous } \\
\text { Metals }\end{array}$ & 2 & 3 & 383 & 205 & 0.06 & 23 & 0.7 & 33 \\
\hline $\begin{array}{l}\text { Non-Metallic } \\
\text { Minerals }\end{array}$ & 28 & 23 & 3331 & 791 & 0.06 & 203 & 0.8 & 254 \\
\hline $\begin{array}{l}\text { Textile and } \\
\text { Leather }\end{array}$ & 19 & 15 & 562 & 445 & 0.28 & 156 & 1.1 & 142 \\
\hline $\begin{array}{l}\text { Wood and W. } \\
\text { Products }\end{array}$ & 9 & 11 & 6 & 245 & 0.55 & 3 & 0.9 & 4 \\
\hline
\end{tabular}

Outlined heat and electricity production improvements are function of the industrial sectors characteristics. Again, based on the data reported in Table 5, there are sectors with high percentage of possible CHP improvement like the Chemical, the Food and the Textile due to the low temperature heat requests. For other sectors, like the Machinery and the Wood product, CHP production improvements are of less interest due to the high temperature requested that could still affect the electrical efficiency.

\section{Local Energy Balance and CHP potential}

The knowledge of the local energy balance can help regulators to assess the effectiveness of current regulations and to identify new strategies suitable for efficiency improvements.

To get the local industrial energy balance starting from the national industrial energy balance it is possible to follow several pathways. The first step is to through improve the knowledge of the local area. The knowledge of industrial structure can help to identify industrial energy requests; also, the knowledge of the average number of employees for each industrial sector can give information about the industrial consumption in the investigated area. From the Italian TSO (Transmission System Operator) it is possible to get information about local energy consumption on a specific area. All those indicators can help to evaluate the local energy balance. This approach has been applied to the North-East regions of Italy and the three outlined balances present an absolute error of $3.2 \%$ on the total energy consumption of the area. This result permits to verify the relation between national and local consumptions that are linked to the number of industries and employees 
and to the local energy consumption. In this paper, it is studied and computed the balance obtained considering as reference information, the local energy consumption in four regions of the North-East of Italy (Veneto, Trentino Alto Adige, Friuli Venezia Giulia and Emilia Romagna); the result is summarized in Table 6.

The effective outlined method can be applied also to smaller areas, for example rural areas to gather local information. To prove its potential, the method has been applied to a small region including three towns in the countryside. The outlined energy balance for the towns can help to investigate local opportunity. The local energy balance is summarized in Table 7.

Table 6. Energy consumption of North-East Italian enterprises.

\begin{tabular}{|c|c|c|c|c|c|c|c|c|}
\cline { 2 - 9 } \multicolumn{1}{c|}{} & $\begin{array}{c}\text { Total } \\
\text { products }\end{array}$ & $\begin{array}{c}\text { Solid } \\
\text { fuels }\end{array}$ & $\begin{array}{c}\text { Oil } \\
\text { (total) }\end{array}$ & Gas & $\begin{array}{c}\text { Total } \\
\text { Renewables }\end{array}$ & $\begin{array}{c}\text { Wastes } \\
\text { (non } \\
\text { ren.) }\end{array}$ & $\begin{array}{c}\text { Derived } \\
\text { heat }\end{array}$ & Electricity \\
\hline $\begin{array}{c}\text { Extraction of crude } \\
\text { petroleum and gas }\end{array}$ & 26 & 0 & 0 & 25 & 0 & 0 & 1 & 1 \\
\hline $\begin{array}{c}\text { Coke and refined } \\
\text { petroleum products }\end{array}$ & 123 & 1 & 76 & 7 & 0 & 0 & 27 & 12 \\
\hline Extraction of coal & 0 & 0 & 0 & 0 & 0 & 0 & 0 & 0 \\
\hline $\begin{array}{c}\text { Electricity, gas and } \\
\text { steam supply }\end{array}$ & 249 & 0 & 0 & 9 & 0 & 0 & 119 & 120 \\
\hline $\begin{array}{c}\text { Water supply and } \\
\text { management }\end{array}$ & 85 & 0 & 0 & 0 & 0 & 0 & 0 & 85 \\
\hline $\begin{array}{c}\text { Iron and steel, non- } \\
\text { ferrous metals }\end{array}$ & 1156 & 392 & 19 & 363 & 0 & 0 & 18 & 363 \\
\hline $\begin{array}{c}\text { Chemical and } \\
\text { pharmaceutical }\end{array}$ & 843 & 0 & 96 & 215 & 1 & 15 & 254 & 261 \\
\hline $\begin{array}{c}\text { Non-metallic } \\
\text { minerals }\end{array}$ & 1948 & 94 & 594 & 784 & 37 & 79 & 42 & 318 \\
\hline Transport equipment & 52 & 0 & 0 & 0 & 0 & 0 & 11 & 40 \\
\hline Machinery & 1068 & 0 & 80 & 441 & 0 & 0 & 5 & 541 \\
\hline $\begin{array}{c}\text { Mining and } \\
\text { quarrying }\end{array}$ & 22 & 0 & 4 & 6 & 0 & 0 & 0 & 11 \\
\hline $\begin{array}{c}\text { Food products, } \\
\text { beverages and } \\
\text { Tobacco }\end{array}$ & 952 & 0 & 57 & 420 & 11 & 0 & 95 & 368 \\
\hline $\begin{array}{c}\text { Paper products and } \\
\text { print }\end{array}$ & 676 & 0 & 21 & 205 & 0 & 0 & 189 & 261 \\
\hline Wood products & 207 & 0 & 0 & 16 & 46 & 0 & 14 & 132 \\
\hline Constructions & 120 & 0 & 11 & 72 & 0 & 0 & 0 & 37 \\
\hline $\begin{array}{c}\text { Textiles, apparel, } \\
\text { leather }\end{array}$ & 214 & 0 & 15 & 108 & 0 & 0 & 7 & 84 \\
\hline Other manufacturing & 312 & 1 & 12 & 6 & 15 & 2 & 38 & 238 \\
\hline
\end{tabular}


Table 7. Energy consumption of enterprises in the small selected rural area.

\begin{tabular}{|c|c|c|c|c|c|c|c|c|}
\hline & $\begin{array}{c}\text { Total } \\
\text { products }\end{array}$ & $\begin{array}{l}\text { Solid } \\
\text { fuels }\end{array}$ & $\underset{\text { (total) }}{\text { Oil }}$ & Gas & $\begin{array}{c}\text { Total } \\
\text { Renewabl } \\
\text { es }\end{array}$ & $\begin{array}{l}\text { Wastes } \\
\text { (non } \\
\text { Ren.) }\end{array}$ & $\begin{array}{c}\text { Derived } \\
\text { heat }\end{array}$ & Electricity \\
\hline & ktoe & ktoe & ktoe & ktoe & ktoe & ktoe & ktoe & ktoe \\
\hline $\begin{array}{l}\text { Chemical } \\
\text { and } \\
\text { Petroche } \\
\text { mical }\end{array}$ & 0.201 & 0 & 0.032 & $\begin{array}{c}0.04 \\
6\end{array}$ & 0 & 0.004 & 0.056 & 0.064 \\
\hline $\begin{array}{c}\text { Food and } \\
\text { Tobacco }\end{array}$ & 2.746 & 0 & 0.167 & $\begin{array}{c}1.23 \\
4\end{array}$ & 0.009 & 0 & 0.243 & 1.093 \\
\hline $\begin{array}{c}\text { Iron and } \\
\text { Steel }\end{array}$ & 0.364 & 0.153 & 0.006 & $\begin{array}{c}0.09 \\
2\end{array}$ & 0 & 0 & 0.002 & 0.111 \\
\hline $\begin{array}{c}\text { Machiner } \\
y\end{array}$ & 1.605 & 0 & 0.134 & $\begin{array}{c}0.65 \\
0\end{array}$ & 0 & 0 & 0.011 & 0.810 \\
\hline $\begin{array}{c}\text { Non- } \\
\text { specified } \\
\text { (Industry) }\end{array}$ & 0.683 & 0.001 & 0.012 & $\begin{array}{c}0.01 \\
0\end{array}$ & 0.034 & 0.001 & 0.091 & 0.534 \\
\hline $\begin{array}{l}\text { Textile } \\
\text { and } \\
\text { Leather }\end{array}$ & 1.562 & 0 & 0.059 & $\begin{array}{c}0.76 \\
0\end{array}$ & 0 & 0 & 0.059 & 0.684 \\
\hline $\begin{array}{l}\text { Wood } \\
\text { and W. } \\
\text { Products }\end{array}$ & 0.895 & 0 & 0 & $\begin{array}{c}0.06 \\
3\end{array}$ & 0.189 & 0 & 0.060 & 0.583 \\
\hline
\end{tabular}

Following the previously described approach it is possible to determine the local CHP potential as possibility for new local energy production.

Table 8 shows how it is possible to improve the local energy production and in which sectors the improvement could be more effective. The results achieved showed that high potential improvement could be obtained in the food sector but also in the machinery and textile sectors.

Table 8. Estimation of new CHP production of three towns.

\begin{tabular}{|c|c|c|c|c|c|c|}
\hline & $\begin{array}{c}\text { Heat from } \\
\text { boilers }\end{array}$ & $\begin{array}{l}\text { Electricity } \\
\text { from grid }\end{array}$ & $\begin{array}{l}\text { Further heat } \\
\text { from CHP }\end{array}$ & $\begin{array}{l}\text { Further heat } \\
\text { from CHP }\end{array}$ & $\begin{array}{l}\text { TH/EL } \\
\text { CHP }\end{array}$ & $\begin{array}{l}\text { Further } \\
\text { electricity } \\
\text { from CHP }\end{array}$ \\
\hline & ktoe & ktoe & $\%$ & ktoe & & ktoe \\
\hline $\begin{array}{l}\text { Chemical and } \\
\text { Petrochemical }\end{array}$ & 0.028 & 0.046 & 0.423 & 0.012 & 0.9 & 0.013 \\
\hline Food and Tobacco & 0.874 & 0.929 & 0.239 & 0.209 & 1.1 & 0.190 \\
\hline Iron and Steel & 0.174 & 0.088 & 0.060 & 0.010 & 0.7 & 0.015 \\
\hline Machinery & 0.675 & 0.797 & 0.500 & 0.338 & 1.5 & 0.225 \\
\hline $\begin{array}{l}\text { Non-specified } \\
\text { (Industry) }\end{array}$ & -0.067 & 0.496 & 0.487 & 0.000 & 0.9 & 0.000 \\
\hline $\begin{array}{l}\text { Textile and } \\
\text { Leather }\end{array}$ & 0.656 & 0.649 & 0.278 & 0.182 & 1.1 & 0.166 \\
\hline $\begin{array}{l}\text { Wood and W. } \\
\text { Products }\end{array}$ & -0.104 & 0.515 & 0.549 & 0.000 & 0.9 & 0.000 \\
\hline Total & & & & 0.751 & & 0.609 \\
\hline
\end{tabular}




\section{Local by-product exploitation in food and beverage sector}

Local investigation carried out with Energy Service Companies helps to verify the real industrial structure of the considered towns. The reference area highlights a rural structure with high concentration of enterprises linked to the agriculture and food processing. High vinery concentrations and intensive wine cultivation suggests the exploitation of agriculture by-products for energy use improving the use of local renewable energy sources.

The area under investigation is composed by three towns and the total surface is 64 square kilometres. The area dedicated to grape growing is 18 square kilometres. The grape vine cultivation is subjected to the plants management, and during the cold months grapevines are trimmed getting wood by-product (the so called "grape canes") from the cultivation. The wood by-product can be collected and dried in order to be used as fuel in a biomass furnace and producing heat for industrial purposes.

Preliminary analysis provides the specific wood by-product production. Trimmed wood has a relative humidity of $45 \%$. The wood yield is $270 \mathrm{t} / \mathrm{km}^{2}$. After a natural drying process, the relative humidity becomes $10 \%$ with a wood yield of $150 \mathrm{t} / \mathrm{km}^{2}$. The lower heating value of the dry biomass can be estimated as $4.6 \mathrm{kWh} / \mathrm{kg}$ while the collection cost is $100 € / \mathrm{t}$ of dry wood. The cost consider the use of energy for collection and wood processing [7].

The use of local wood by-product for energy purposes allows a $\mathrm{CO}_{2}$ reduction due to a cutback avoiding of fossil fuels utilization. Switching from natural gas to grape canes for heat production can provide a $\mathrm{CO}_{2}$ reduction of $2500 \mathrm{tCO}_{2} /$ year

Literature investigations provided information about energy consumption in wineries. For a typical facility with a production of 3 million of litres of wine per year the electrical energy consumption is $11 \mathrm{kWh} / 100$ litres of wine, the thermal energy consumption is $1 \mathrm{kWh} / 100$ litres of wine. Energy consumption can vary from $3 \mathrm{kWh} / 100$ litres for facilities with more than 5 million of litres of product to $25 \mathrm{kWh} / 100$ litres for facilities with less than $25 \mathrm{kWh} / 100$ litres [8].

The use of pruning wood in an Italian winery has been investigated by the use of a pilot plant [9]. Winery has about $2.5 \mathrm{~km}^{2}$ of vineyards with a yearly production of 150 tons of pruning wood. Biomass is burned in a boiler which generates $720 \mathrm{MWh}$ of heat. Energy is used for space and water heating and for space cooling by means of an absorption chiller. The use of pruning residues can provide the $42 \%$ of the overall energy need of the winery.

The use of local wood by-product for energy purpose can be carried out in local industries not necessary linked to vineyards. The exploitation can be made in the local industrial area with the cooperation of the consortium for industrial development. The reduction of fossil fuel consumption in local enterprises can be reached using biomass collected from local agricultural enterprises. The vineyards are the main providers of wood for energy use but is not excluded the utilization of different sources like woodlands maintenance. However, additional investigations are needed to verify the technical and economic feasibility of wood by-products exploitation for energy purposes in the selected area.

\section{Conclusions}

The developed method can support the energy investigation on Italian areas, providing contribution to the identification of energy efficiency opportunity. Using national energy balance is possible to determine the local energy balance through local information like number of employees, number of enterprises and electrical energy utilized in the selected area. One possible outcome of the model is the identification of CHP potential improvements in the investigated region. The method can be applied also to local community and small areas. Cooperation on research and detailed investigations on site, 
showed local opportunity and potential exploitation of local resources. Renewable energy sources available on-site can improve the by-products exploitation following local development. The exploitation of renewable sources can support local industrial sectors. Indepth investigations carried out in cooperation with local enterprises are necessary to better identify the technical and economic potential of the by-products exploitation.

\section{References}

1. "Priorities for 2014-2020 - Regional Policy - European Commission.” [Online]. Available: http://ec.europa.eu/regional_policy/en/policy/how/priorities.

[Accessed: 28-Apr -2017]

2. "Energy efficiency in industry will rise, study finds - European Commission." [Online]. Available: https://ec.europa.eu/energy/en/news/energy-efficiency-industry-will-risestudy-finds. [Accessed: 28-Apr -2017]

3. “ATECO (Classification of Economic Activity) 2007." [Online]. Available: https://www.istat.it/en/archive/17959. [Accessed: 28-Apr -2017]

4. Eurostat, "Energy balances." [Online]. Available: http://ec.europa.eu/eurostat/web/energy/data/energy-balances. [Accessed: 28-Apr 2017]

5. GSE-Gestore Servizi Energetici, “Assessment of the national potential for highefficiency cogeneration and efficient district heating," 2015

6. "ICF: Strategic Consulting \& Communications for a Digital World." [Online]. Available: https://www.icf.com/. [Accessed: 28-Apr -2017]

7. Saorin, "Studio di fattibilità di due filiere per la valorizzazione energetica dei sarmenti di vite," 2013

8. T.U. of M. (UPM), “Tesla, Transfering Energy Save Laid on Agroindustry."

9. "Progetto Biomasse: Energia Rinnovabile per le Aziende Agricole derivante da scarti di Potature dei Vigneti - ERAASPV - GELSO GEstione Locale per la SOstenibilità ambientale." [Online]. Available: http://www.sinanet.isprambiente.it/.

[Accessed: 28-Apr-2017] 